IRA-International Journal of Management \&

Social Sciences

ISSN 2455-2267; Vol.08, Issue 02 (August 2017)

Pg. no. 162-174

Institute of Research Advances

http://research-advances.org/index.php/RAJMSS

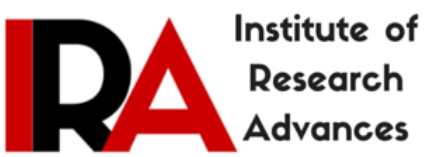

\title{
The Beginning of Dutch and English Conflict in Banda and Moluccas in the Early Seventeenth Century
}

\author{
A S Shngreiyo, $\mathrm{PhD}$ \\ Post-Doctoral, Jawaharlal Nehru University, India.
}

Type of Review: Peer Reviewed.

DOI: http://dx.doi.org/10.21013/jmss.v8.n2.p4

\section{How to cite this paper:}

Shngreiyo, AS. (2017). The Beginning of Dutch and English Conflict in Banda and Moluccas in the Early Seventeenth Century. IRA-International Journal of Management \& Social Sciences (ISSN 2455-2267), 8(2), 162-174. doi:http://dx.doi.org/10.21013/jmss.v8.n2.p4

(C) Institute of Research Advances.

\section{(cc) BY-NC}

This work is licensed under a Creative Commons Attribution-Non Commercial 4.0 International License subject to proper citation to the publication source of the work.

Disclaimer: The scholarly papers as reviewed and published by the Institute of Research Advances (IRA) are the views and opinions of their respective authors and are not the views or opinions of the IRA. The IRA disclaims of any harm or loss caused due to the published content to any party.

Institute of Research Advances is an institutional publisher member of Publishers Inter Linking Association Inc. (PILA-CrossRef), USA. The institute is an institutional signatory to the Budapest Open Access Initiative, Hungary advocating the open access of scientific and scholarly knowledge. The Institute is a registered content provider under Open Access Initiative Protocol for Metadata Harvesting (OAI-PMH).

The journal is indexed \& included in WorldCat Discovery Service (USA), CrossRef Metadata Search (USA), WorldCat (USA), OCLC (USA), Open J-Gate (India), EZB (Germany) Scilit (Switzerland), Airiti (China), Bielefeld Academic Search Engine (BASE) of Bielefeld University, Germany, PKP Index of Simon Fraser University, Canada. 


\begin{abstract}
Why Christopher Columbus did discovered America the new world, why did Vasco da Gama discovered the sea route to reach India. They went and risk their life if search of the Spice Islands. The spices that European was searching were found in Indonesia Archipelago, Bandas famous for nutmeg and mace and Moluccas for its clove. After the formation of the East India Company in the early seventeenth century both the Dutch and English were competing against each other and outmaneuver one another for control of the islands. In the end, it was the Dutch who emerge victories. The Dutch established a monopoly on the spice trade from the Moluccas. They gained control over the clove trade through an alliance with the sultan of Ternate. Dutch occupation of the Banda's gave them control of the nutmeg trade. Dutch control of the region was fully realized when Malacca was captured from the Portuguese in 1641. The Dutch were quite merciless when it suited their purposes; sometime obliterate the whole native population. By its brutal conquest over the Spice Islands they were able to control over the spice trade. Nevertheless, the English were not left behind whenever there is opportunity they set in to take the advantage of the sour relation between the native and Dutch, as the English played a role of more mercantile communities than occupation. The beginning of the seventeenth century is very important for the two companies as it decide the fate of the spices trade. Both companies were not willing to back out.
\end{abstract}

Keywords: Beginning Dutch and English Conflict in Banda and Moluccas Early Seventeenth Century

The modern Indonesian province of Moluccas covers all the islands to the East of Sulawesi or known as Celebes and Timor as far as New Guinea, including the Banda Islands and it has its capital at Amboyana. Nevertheless, in the sixteenth century the term Moluccas were used to designate only the five small islands: Ternate, Tidore, Motir, Makian and Batchian. ${ }^{1}$ Which straddle the equator off the west coast of Halmahera and which at time were the only islands where the cloves was cultivated, though it almost certainly grew wild on several other islands. However, Francois Pyrard mentioned there were nine islands and known as Moluccas, these were Ternate, Amboyan,

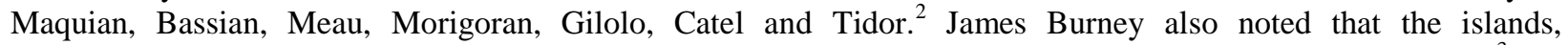
comprehended under the name of the Moluccas were only five, Terrenate, Tidore, Motir, Maquian and Bachian. ${ }^{3}$

The word Moluccas derive from Arabic mean Royal Islands, each of them being anciently the residence of a sovereign nation. The name is now generally given to the archipelago between Celebes and New Guinea, and between Giolo and Banda. Some authors are of the opinion, that the name for these islands is properly Moloc, which, in the language of the natives, signifies head or chief; they being esteemed principals, among several groups of islands, in the same seas. Others derive the name from Моисо, an Arabic word, signifying 'per excellence' of the kingdom. The Spanish called las Moluccas at the time of their discovery, and long after, latterly the Spanish have written the name as las Moluccas.

The Moluccas islands, which produced cloves, consist of five islands. The chief one is called Ternate and other Tidore, Motir, Makyan and Bachian. ${ }^{4}$ Tome Pires mentioned that: 'these five islands produced about six thousand bahars of cloves a year-sometimes a thousand more, or a thousand less. ${ }^{5}$ Captain Andres de Urdaneta wrote that, 'The islands of Maluco which produced cloves are Tidore, Ternate, Motir, Makyan, and Bachian. In none of the others, though there are many islands, they gather cloves. In Ternate, they gather 3500 quintals of cloves. In Tidore, 3500 quintals. In Motil, 1000 quiiitals. In Makaan, 3500 quintals. In Bachian, 600 quintals. In all the five islands, when there is a good harvest, 1 1,600 quintals a little more or less ; at other times they do not gather more than 5000 or 6000 quintals. $^{6}$

Francois Pyrard notes that cloves grew only at Moluccas. All around the tree grows no other herb, because the roots are so hot that they attract all the humidity. This is proved by placing a sack of cloves over a vessel full of

\footnotetext{
${ }_{1}^{1}$ Tuckey, James Hingston, (1815). Maritime Geography and Statistics. vol. II, p. 395.

${ }^{2}$ Gray, Albert, (ed.), (2000). The Voyage of Francois Pyrard. vol. II. Part. I, p. 166.

${ }^{3}$ Burney, James, (1803). A Chronological History of the Discoveries in the South Sea. Part. I, p. 99.

${ }^{4}$ Ternate as the Chief Island mentioned by both Tome Pires and Francois Pyrard.

${ }^{5}$ Cortsao, Armando, (ed.), (2005). The Sumo Oriental of Tomes Pires. vol. I. p. 213.

${ }^{6}$ Markham, Clements, (ed.), (1911). Andres de Urdaneta, Narrative of the Voyage to Malucos, pp. 84-85.
} 
water; the water is consumed and diminished, while the cloves are increased in bulk. He further stated that while the flower of the clove is blooming it white; then it turns to yellow, and at length to red, and it is then the clove is begotten in the flower, and the scent is strongest and best. The scent is the sweetest and most delightful that can be imagined; and one standing within the full forces of these flowers would say the whole air was perfumed with the scent. When the clove is ripe, it falls to the ground. They were gathered and steeped in sea water, then dried upon wicker-trays under which fire is placed, the fumes turning the cloves black, which before was red. ${ }^{7}$ For the European it was one of the greatest wonder to witness from their observation of the sweet scents, which they exhale the air is so filled that the wind bears them six or seven leagues away. Yet it was a tragedy for it cost men dear to go for them, seeing that sometimes they lose their lives or endure suffering in the quest. ${ }^{8}$ Christopher Fryke who visited in the 1680s, wrote that: "when it is green it smells so fine and sweet, that nothing can be compared to it. ${ }^{9}$ He further wrote that the smell is so strong, that some people have been suffocated with it when they have been busy with too great quantities and in too close a place..$^{10}$

Like the cloves of the Moluccas and sandalwood of Timor, Bandanas nutmeg and mace were very highly prized because of rarity. According to Tome Pires: 'it was common saying among the Malaccan merchants who trade in these precious goods that God created Timor for sandalwood and Banda for mace and the Moluccas for cloves, and that merchandise is not known anywhere else in the world except in these places; and I asked and enquired very diligently whether they had this merchandise anywhere else and everyone said not. ${ }^{11}$ Certainly, for the European it is very important commodity because nutmeg and mace were used, like pepper and other spices, to season the insipid fare on which they had to subsist during the winter months when no fresh mat was to be had. It also used for both cooking and medicine.

The islands present the evident appearances of having undergone some great natural convulsion, being singularly broken, and rising in enormous peaks from the abysses of the ocean. Most of these islands were also volcanoes either extinct or in a state of eruption. The nature of the climate and the soil, in most of these islands prevent cultivating any kind of grain; the former being for one reason, a constant rain and the other an uninterrupted drought; while the latter is in general either spongy or rocky. Hence, the staple food of the islanders is derived from the sago palm, which nature has given to them in vast profusion, as if to compensate for the corn she has denied them. The chief riches of these islands however, and without which they would never attracted the notice of European are their nutmeg and cloves, which are indigenous in no other region of the globe found except in these islands. ${ }^{12}$ This marvelous quantity of cloves and nutmeg, which grow in no other part of the world expect in these in islands, and covered all parts of the islands. This is the reason frequented by foreign merchants from different parts of the world: "who come here from a quarter of the word to get that spices, Christians, Chinese, Indians and Arabs. ${ }^{13}$ According to Hamilton, writing in the early eighteenth century mentioned that; 'They are small Islands, but produce the greatest Quantities of Cloves and Nutmegs, of all the Molucca Islands. ${ }^{14}$ Tavernier also mentioned: 'The four places where cloves grow in abundance are the land of Amboine, (Amboyna), Gilolo, Ceram and Boeroe (Buru) in the islands of Molucca Sea. ${ }^{15}$

In the Moluccas, there was only a limited navigation between the islands. Barbosa notes that the Ambonese possessed similar rowing boats in which they would make sudden raids from the island to another, making war, and taking captives or slaying one another. ${ }^{16}$ But the Moluccas possessed no junks or other crafts with high sides suitable for carrying cargo and were therefore dependent on foreign traders to bring them the goods they imported and take away those they produced for export. The Bandanese, on the other hand, constructed quite large ships and carried out extensive navigation throughout the Indonesian Archipelago. Whereas in the Moluccas, the population harvest

${ }^{7}$ Gray, Albert, (ed.), (2000). The Voyage of Francois Pyrard. vol. II. Part. II: pp. 357-358.

${ }^{8}$ Gray, Albert, (ed.), (2000). The Voyage of Francois Pyrard. vol. II, pp. 170-171.

${ }^{9}$ Fayle, C. Earnest, (ed.), (1997). Voyages to the East Indies, p. 88.

${ }^{10}$ Fayle, C. Earnest, (ed.), (1997). Voyages to the East Indies, pp. 88-89.

${ }^{11}$ Cortsao, Armando, (ed.), (2005). The Sumo Oriental of Tomes Pires. vol. I, p. 204.

${ }^{12}$ Tuckey, James Hingston, (1815). Maritime Geography and Statistics. vol. II, p, 396.

${ }^{13}$ Gray, Albert, (ed.), (2000). The Voyage of Francois Pyrard, p. 166.

${ }^{14}$ Hamilton, Alexander, (1995). A New Account of the East-Indies, vol. I, p. 143.

${ }^{15}$ Crooke, William. (ed.), (2007). Tavernier. Travels in India, vol. I, p. 14.

${ }^{16}$ Dames, L.M. (ed.), (1989). The Book of Duarte Barbosa. vol. II, p. 119. 
the cloves, but left the task of exporting to visiting merchants from Malacca and Java. The Bandanese themselves shied nutmeg and mace to other islands, where they sold it to foreign merchants. They also bought small quantities of cloves in the Moluccas and in Amboynas in exchange for Indian cloth and the gold and ivory they obtained from other islands. The cloves they resold in the Banda Islands to the Javanese and Malaccans and, later to the Portuguese. Tome Pires tells us that the voyage from the Moluccas to Banda by way of Amboyna took 12 to 15 days in the monsoon. ${ }^{17}$

Some merchants, indeed, would buy cloves, as well as nutmeg and mace, in Banda rather than in the Moluccas because the voyage from Malacca to the Moluccas and back took almost twice as long as the return voyage to Banda. They would leave Malacca in January or February of each year and having completed their business and loaded their ships in Banda by the beginning of July, would sail for Malacca, which they would reach in August. To go on to the Moluccas they needed to leave Banda by the beginning before the end of May and, because of the northeast monsoon, had to remain in the Moluccas until the following January, when favourable winds enable them to return Malacca. Pires notes that the king of Moluccas, who know about the things of Banda, sigh for us, as will be told when the nobles islands are described. Moreover, the merchants who used to sail there used to buy for old pots, trinkets, and beads from Cambay and other things like that, so that there is no doubt that Banda is wealthier now. Banda also has cloves, which come in loads from Moluccas to Amboina and from Amboina to Banda, this in twelve of fifteen days with the monsoon. A bahar of cloves is worth the same as a bahar of mace, and one of mace the same as seven of nutmeg, and they will not sell you mace and nutmeg together, that is, if you want a bahar of mace you have to buy seven bahars of nutmeg, because otherwise the merchandise could not stand it because the nutmeg would be lost if they did not sell it in this way. ${ }^{18}$

Burney mention the comparative estimation in which the different European commodities were held by the natives, appears from the following rates which were settled as the price of a bahar of cloves (the bahar being 406lbs. i. e. four cantari, or quintals of $100 \mathrm{lbs}$. each, and $6 \mathrm{lbs}){ }^{19}$

\begin{tabular}{|ll|l|}
\hline Red cloth of good quality & 10 yards & For one bahar $(406 \mathrm{lbs}$.) of cloves \\
Cloth of an inferior quality & 15 yards & \\
Linen - & 26 yards & \\
Drinking glass & 35 & \\
Hatchets & 15 & \\
Gujarat cloth & 10 yards & \\
Knives & 150 & \\
Timbrels of their own country & 3 & \\
Quicksilver & 17 cathil & \\
\hline
\end{tabular}

There is some evidence to suggest that when regular commercial relations began to develop between Malacca and Makassar in the late sixteenth century, the Bandanese with other Indonesian merchants participated in this growing commerce to bring spices to Makassar. By the early seventeenth century the Makassarese themselves were actively engaged in this trade. In 1613, John Jourdian mentioned that, though Makassae itself yielded nothing nut rice, there was much trade in goods from the Moluccas Banda and Johore: from whence there is yearly brought store of cloves mace, nutmeg and sandlewoods which they barter for rice and gold; which commodities they have in former times sold to the Portuguese (i. e. from Malacca) in truck of their clothing of Coromandel and Gujerat. ${ }^{20}$ Barbosa writing in much earlier in 1518, mentions their legitimate trading activities in the spice islands, which were evidently already well established. He wrote that: 'their boats are badly built, and therein they come to take loads of cloves in these islands, also copper Cambay cloths and tin and they take thither for sale very long and broad oneedged swords and other ironwork and a good quantity of gold. ${ }^{, 21}$ One other gruesome commodity, according to Barbosa, they also acquired from the spices islands: 'these folks are eaters of human flesh, and if the king of Maluco

\footnotetext{
${ }^{17}$ Cortsao, Armando, (ed.), (2005). The Sumo Oriental of Tomes Pires. vol. I, p. 207.

${ }^{18}$ Cortsao, Armando, (ed.), (2005). The Sumo Oriental of Tomes Pires. vol. I, p. 207.

${ }^{19}$ Burney, James, (1803). A Chronological History of the Discoveries in the South Sea. Part. I, p. 104.

${ }^{20}$ Foster, William, (ed.), (1905). John Jourdian, The Journal of a Voyage to the East Indies, pp. 294-295.

${ }^{21}$ Dames, L.M. (ed.), (1989). The Book of Duarte Barbosa. vol. II, p. 204.
} 
wishes to put to death any person condemned by law they beg him to be delivered to them to eat as if they were asking for a pig. ${ }^{22}$

According to Pires, the Javanese and Malacca traders would sail to Moluccas and Banda Islands each year taking with them cotton and silk from Cambay Coromandel and Bengal. The best of this cloth they would sell in the north Javanese ports for Chinese copper coins known in Portuguese as caxas, caixas, sapecas or bazarucos, ${ }^{23}$ and other goods of inferior quality (de baixa sorte) and then sail to Sumbawa and Bima in the east of that island, where they would take on water and food supplies and buy rice and coarse cloth for the caxas. This rice and cloth they in turn exchanged for nutmeg mace and cloves when they reached the spices islands. ${ }^{24}$ They also purchased horses in Sumbawa and Timor, sappan wood in Sumbawa, sulphur and rottan in Solar and slaves in all the Lesser Sunda Islands for sale in the east. Pires mentioned that, there was some trading in these goods in the other direction; slaves, horse timber and other Sumbawan products were taken to Java by the islanders, who possessed many prahus. ${ }^{25}$ Barbosa notes the list among the trade goods brought by their merchants to the Spice Islands: 'those who come hither to buy it bring Cambaya cloths, some of cotton and some of silk, and much copper, quicksilver, vermilion, tin, lead and certain hairy caps from the Levant, and large bells, for each of which they gave twenty baares of mace. $^{26}$

It was the demands of the western world, which stimulated this commerce and the adventure of those merchants may be considered as the first link in that long commercial chain, which brought the spices of the Moluccas through many nations to the gates of Rome. The inhabitants of which were ignorant of the countries, which produced them, and of the means which they obtained them. The spices obtained by these adventures at the extremity of the Archipelago were carried to the emporia of the west to Malacca, Achin, and some of the ports of Java, where they were purchased in the earlier ages of commerce, by the Indian merchants, and in later times by these, jointly with the Arabs. ${ }^{27}$

The Moluccas, though their prominence in the affairs of the further east commences later, were among the first islands explored by the Portuguese. Antonio de Abreu was dispatched in the beginning of the sixteenth century to examine their situation, and procure specimens of their celebrated products. The voyage led him among groups of islets, various in size and form, but all beautiful from the abundance of their vegetation. At Amboyna he was received with honour and hospitality. The native races of the Archipelago have in most instances welcomed strangers with a confidence and cordiality seldom repaid. One of the ships under De Abereu was separated from the main convoy while sailing back to Malacca, encountering a storm, was wrecked on the shore of a desert isle. There his fate would have been to perish miserably by a hunger had not some fishermen, paddling along the coast, observed a strange barque thrown on the beach, and making for it discovered the desolate mariners. They took them on board their prahus and carried them to Amboyana. They were received by the friendly natives with a hospitality characteristic of the Moluccan race. They were clothed fed, and sheltered with a humanity which should have secured their attachment, but failed to prevent their treachery. ${ }^{28}$

The result of De Abreu's voyage was not important. It revealed to the European eye what had long been celebrated by rumours, romance, and the accounts of Arabian travelers. At each places European landed, a small pillar was set up to commemorate their visit. The view of Moluccas, enchanting in its beautiful variety, riveted their gaze as they sailed slowly through the tortuous channels, which separated the islands. The nutmeg tree, dispersed in groves, attracted every eye by the richness of it flowers and fruit, variegated in hue like the iris, changing from blue to brown, and thence into a flame colour, which deepens into crimson. The ample beauties of the islands were thus exaggerated in the ideas of the earl voyagers, and their credulity accepted every account with equal faith. ${ }^{29}$

\footnotetext{
${ }^{22}$ Dames, L.M. (ed.), (1989). The Book of Duarte Barbosa. vol. II, pp. 204-205.

${ }^{23}$ Satow. M. Ernest, (ed.), (1900). The Voyage of Captain John Saris to Japan. p. 213.

${ }^{24}$ Cortsao, Armando, (ed.), (2005). The Sumo Oriental of Tomes Pires. vol. I, p. 202.

${ }^{25}$ Cortsao, Armando, (ed.), (2005). The Sumo Oriental of Tomes Pires. vol. I, p. 203.

${ }^{26}$ Dames, L.M. (ed.), (1989). The Book of Duarte Barbosa. vol. II, p. 198.

${ }^{27}$ Crawford, John, (1820). History of the Indian Archipelago. vol. III, pp. 148-149.

${ }^{28}$ Crawford, John (1820). History of the Indian Archipelago. vol. III, p. 406.

${ }^{29}$ Hoarse, St. John, (1853). The Indian Archipelago. vol. I, p. 86.
} 
When Francis Seiran, the shipwrecked captain, was at Amboyna, he experiences his company to numerous quarrels with the natives. The Moluccans quickly discovered the character of the wanders they had welcomed to their towns. Nevertheless, they endeavoured to secure their friendship, as they perceived and feared their power. It was during the struggle between the kings of Ternate and Tidor. Each was solicitous to secure the alliance with the strangers. Ben Acorala, Sultan of Ternate, as the more powerful, succeeded in the struggle. The success of Ternate over his neighouring island was due to possess of largest fleet called 'paraos. ${ }^{30}$ With ten vessels and a thousand men, he proceeded to Amboyna, where he met the captain and instructed him, after a fashion of his own, in the condition and resources of the Moluccan islands. The influence of Portugal was thus, by the accident of Seiran's shipwreck, established in the Spice Islands. ${ }^{31}$

The charm of romance is upon them. They have been celebrated as the possessors of fatal gift. In the earliest times before the Arabian voyages navigated the Archipelago, rumours of the wealthy Moluccas were circulated throughout the Europe. The courts of Europe plunged with lust and luxury, favoured with their patronages the merchant who brought from the East Spices to regal their senses, satiated with common delicacies. Indeed, so begin the adventurers of Christendom were attracted to these remote islands by the nutmegs and cloves so highly priced among the epicures of Europe. The natives of the Spice Islands could not conceal their riches but instead of remaining undiscovered their wealth, extraordinary as it is, was exaggerated by the imaginative travelers of the early ages. $^{32}$

The trades of Moluccas spices were carried out to Europe through many stages by land and sea. The merchants of the east discovered the value of the nutmeg and the clove, and defied the accumulated dangers, which then attended all maritime adventures. We find in the annals of the Moluccas that the Javanese sought their spices in $1332 .{ }^{33}$ Adventurers from the great islands arrived, to form settlement, at the time of the Muslim invasion, when they brought with them the new religion. The trade was open by the Malays, the Javanese, and the Buggies, forming the first ink in the extended chain that drew the spices of these islands as far as the major capital of Europe. They were passed on to Acheen and Malacca, and carried westward by trader after trader until they reached Europe. ${ }^{34}$ At the close of the thirteenth century the spices trade was active in the Archipelago. The Chinese already penetrated deep inside the Archipelago and it appears that they navigated the narrow sea of these group of islands, though they settled nowhere in any numbers until the establishment of European power secured their safety. ${ }^{35}$ Urdaneta wrote that: 'two junks came from China every year, which are a kind of ship which the Chinese use. They come to buy gold and pearls, which they have in great quantity. ${ }^{36}$

The Banda Islands were in the sixteenth century the only known sources of nutmeg. It had six islands, five produced maces and one had fire volcano, which few inhabitants reside. The chief one is called Pulo Banda, which had four ports: Celammon, olutatam, Lontar (Bomtar), Komber (Comber). Neira was also important as it was much frequented by Javanese traders. The other islands had no harbours and so transported their products to Lontor, which provided the best and safest anchorage. ${ }^{37}$ Pires estimates that the annual crop was about 6 or 7 thousand bahars of nutmeg and between 5 or 6 hundred bahars of mace. ${ }^{38}$ Between these two products, mace was always a costlier spice than cloves and much more so than nutmeg. Barbosa writes that: 'in three of them grows abundance of nutmeg and mace on certain trees it spreads the mace like a flower, and above that again another thick rind. One quintal of mace is worth here as much as seven of nutmeg. The abundance is such that they burn it, and it may be had almost for the asking. ${ }^{39}$

${ }^{30}$ Cortsao, Armando, (ed.), (2005). The Sumo Oriental of Tomes Pires. vol. I, p. 214.

${ }^{31}$ Hoarse, St. John, (1853). The Indian Archipelago. vol. I, p. 86.

${ }^{32}$ Hoarse, St. John, (1853). The Indian Archipelago. vol. I, pp. 116.

${ }^{33}$ Crawford, John, (1820). History of the Indian Archipelago. vol. III, p. 140.

${ }^{34}$ Crawford, John, (1820). History of the Indian Archipelago. vol. III, p. 212.

${ }^{35}$ Crawford, John, (1820). History of the Indian Archipelago. vol. III, p. 155, and see also Hoarse, St. John, (1853). The Indian Archipelago. vol. I, p. 118.

${ }^{36}$ Markham, Clements, (ed.), (1911). Andres de Urdaneta, p. 52.

${ }^{37}$ Cortsao, Armando, (ed.), (2005). The Sumo Oriental of Tomes Pires. vol. I, p. 205.

${ }^{38}$ Cortsao, Armando, (ed.), (2005). The Sumo Oriental of Tomes Pires. vol. I, p. 206.

${ }^{39}$ Dames, L.M. (ed.), (1989). The Book of Duarte Barbosa. vol. II, p. 197. 
The importance of the Banda and Moluccas Islands is not just that of an exemplary case study which could have been trade for any other of many geographical regions where Dutch and English economic and strategic interests collided. These tiny and remote islands at that time formed the sole production area of nutmeg, mace and cloves, which constituted the first and foremost reason for sailing to the East-Indies Archipelago. When viewed from the perspective of contemporaries, their importance can hardly be overestimated. It was no coincidence that particular islands of both Moluccas and Banda, the conflict ran so high even threatened to get completely out of control; a frightening prospect to both the English and Dutch companies.

Right from the early decades of the seventeenth century, conflicting interest in these archipelago put relations under such tension that they immediately erupted into violent clashes. By the time the English realized they were not up to Dutch competition, unfortunately for them the cards were already dealt in the archipelago. The Dutch had specific plans with the Spice Islands that constituted their main objective of expansion and monopolizing activities. Since they landed in the archipelago, they expelled the Portuguese from Amboyana and Tidore in 1604, and the Spanish from Makean in 1608, and Baichan in 1609. Their conquests were not very peaceful as often they restore brute force.

In the Banda Islands, as well, relation between the English and Dutch had been strenuous from the beginning. In 1599, the Dutch had reached these ten small islands, at that time world's only producer of nutmeg and mace. They were received cordially by the Bandanese, who were trying to get rid of the Portuguese. Now they finally had found powerful allies, who were all too willing to help them. The Dutch indeed chased the Portuguese, but the Bandanese soon found out they were worse off. In these enterprises the Dutch were aided by the natives, who hoped for a better, and could not imagine a worse master than they had been accustomed to. ${ }^{40}$ Not only were the Dutch military forces much stronger, so that the Bandanese had to accept that they built a fort, they also appeared to have specific ideas about the trade in nutmeg and mace: they wanted the Bandanese to commit themselves exclusively to the Dutch to sell their valuable product. This was to be effectuated by contracts between the Dutch and Bandanese authorities. The Bandanese were uncommitted because they found out that they had signed away their economic freedom under the threat of the Dutch maritime and military presence.

The more the Dutch try to be in touch with the Bandanese, the more they convinced that these were not real partners, only to be brought over by the force of arms or rather ruthless action. Besides, it annoyed the Dutch very much that English merchants who had followed them to Banda and Moluccas, began to buy up the harvest sailing home with nutmeg, mace and cloves, while the Dutch who were fighting the Portuguese and Spanish for opening up its trade in the archipelago. In 1609, the English Company Captain William Keeling visited at the court of Neira and; 'delivered his Majesties Letter, together with a present...it was received with the most state that hath been knowne. ${ }^{41}$ He acquired permission from the Bandanese king to open a factory; he was, however, not allowed to build a fort. ${ }^{42}$ Nevertheless, just as Keeling was starting his business, the Dutch admiral Peiter Verhoeven arrived with instructions of Heern XVII to enforce Dutch authority over the islands. ${ }^{43}$ The Dutch had put many obstacles for the English to trade. ${ }^{44}$ The English were not allowed to buy or sell anything as it was consider the Dutch privileges in the whole of Banda region: 'that The Hollanders had straightly charged them, not to sell any. ${ }^{45}$ The English understood what the Dutch intention as they landed with twenty boats alone with one thousand and two hundred men. ${ }^{46}$ The English silently backed out but the Bandanese started preparation for reprisal.

The Dutch wanted to negotiate with the leaders on Lonthor as it was the largest island. The mission for the Dutch was complete failure. The native ambush while they were on the way to meet the representative and the outcome was the Dutch were slayed including Admiral along with the troops. ${ }^{47}$ It was nothing to do with the English, as the Dutch were very brutal when they try to conquer the Spice Islands, which antagonize the native

${ }^{40}$ Hoarse, St. John, (1853). The Indian Archipelago. vol. I, p. 243.

${ }^{41}$ Purchas, Samuel, (1905). Purchas His Pilgrimes. vol. II, pp. 522-523.

${ }^{42}$ Purchas, Samuel, (1905). Purchas His Pilgrimes. vol. II, p. 531.

${ }^{43}$ Purchas, Samuel, (1905). Purchas His Pilgrimes. vol. II, p. 531.

${ }^{44}$ Purchas, Samuel, (1905). Purchas His Pilgrimes. vol. II, p. 531.

${ }^{45}$ Purchas, Samuel, (1905). Purchas His Pilgrimes. vol. II, p. 532.

${ }^{46}$ Purchas, Samuel, (1905). Purchas His Pilgrimes. vol. II, p. 532.

${ }^{47}$ Purchas, Samuel, (1905). Purchas His Pilgrimes. vol. II, p. 535. 
inhabitants. The Dutch blamed the English Captain Keeling though he had nothing to do about the massacred of Dutch troops in Lonthor. Keeling was in the island of Ay one the Banda's island at the time of the incident. In fact, he even saved five Dutchmen against further attacks by the inhabitants. ${ }^{48}$ The Dutch suspected him to have conspired with the Bandanese to bring them the surprise attack, as well providing with gunpowder and ammunition. Keeling strongly denied the accusation and departs for Labatacca, here too the Dutch hassle the conduct of his trade: 'the Hollanders pulled downe my house, and satisfied me for the same, one hundred and fiftie Dollars, beside fortie of the boords......to let me know, that they had counseled concerning my trade at Labatacca and concluded to permit my quite trade there. ${ }^{49}$ In retaliation for the Verhoeven and his troops, the Dutch devastate a village on Lonthor: "went and took Labatacca: where, as they say, they killed twenty or sixteen persons, and burned the Towne. ${ }^{50}$

One of the hostility by the Dutch was they suspect that the English were helping the Bandanese, but Keeling utterly denied that: 'then followed many presumption of his assistance of the Bandanese, by English Powder and Munitions, by signes and which I omit. ${ }^{, 51}$ Due to this reason, the Dutch force to search on Keeling's ships to see if there was any proof of arms supply to Bandanese. ${ }^{52}$ Nothing was found, but the Dutch subsequently tried to obstruct his trading activities so that he would voluntarily go away. ${ }^{53}$

Later that year, English Captain David Middleton arrived at Banda; he was received in warm reception by the Dutch. The Dutch were curious about his voyage and enquire whether: 'I was a merchants or a man of war. ${ }^{, 54}$ The Dutch made it clear that he was not allowed to take the spices from any Bandanese Islands and threatened him. ${ }^{55}$ The Dutch did not allowed obtaining any spices from Lanthorese. When the Dutch were gone, it was again a turn out to be different picture as the islanders welcome him. ${ }^{56}$ Then Captain David Middleton realized how the mass had complete fear of the Dutch: 'then I understood the whole Estate of the Country, and the Country would be willing to deale with me. ${ }^{57}$ Middleton sailed off to Ay and brought the spices he needed from Lonthor and departed for home, leaving a few of his men on Ay to collect more spices. ${ }^{58}$

It seems that their rivalries in trade respected the Dutch claims only as far as their cannon reached, and although the English appeared only irregularly that certainly bothered the Dutch. The Bandanese began to realize of an alliance, and invite the English to help them while resisting the Dutch, or to create an even more solid coalition. This was a situation where the Dutch did not like to happen as they had been established with great resources and labour to be the sole supplier of spices in Europe.

The treatment that Keeling and Middleton experienced in Banda undoubtedly contributed to the image of the Dutch as exclusive right in Asian trade. The stories brought home to England about the cruel encounters they had with the Dutch, pointed out the need for diplomatic settlements, unless open war on a grand scale, possibly even in Europe, was to become a reality. Unexpectedly, the peace proposal was move forwarded by Dutch Ambassador Noel de Caron on 9 June 1618; he offered a scheme of cooperation between the two rival companies. ${ }^{59}$ The proposal was continue to drag for years at the same time many incidents happen between these two companies. Finally, an agreement was reach and signed on 14 May $1619 .{ }^{60}$ It had thirty articles. The question of uniting the two companies was not suitable for both the companies, thus, it was continue as before. However, it certainly ceases the hostility in the Spice Islands. The principal of the treaty was cooperation for both the countries to trade in the Spice Islands. The

\footnotetext{
${ }^{48}$ Purchas, Samuel, (1905). Purchas His Pilgrimes. vol. II, p. 533.

${ }^{49}$ Purchas, Samuel, (1905). Purchas His Pilgrimes. vol. II, p. 535.

${ }^{50}$ Purchas, Samuel, (1905). Purchas His Pilgrimes. vol. II, p. 538.

${ }^{51}$ Purchas, Samuel, (1905). Purchas His Pilgrimes. vol. II, p. 542.

52 Purchas, Samuel, (1905). Purchas His Pilgrimes. vol. II, p. 536.

${ }^{53}$ Purchas, Samuel, (1905). Purchas His Pilgrimes. vol. II, p. 539.

${ }^{54}$ Purchas, Samuel, (1905). Purchas His Pilgrimes. vol. III, p. 95.

${ }^{55}$ Purchas, Samuel, (1905). Purchas His Pilgrimes. vol. III, p. 95.

${ }^{56}$ Purchas, Samuel, (1905). Purchas His Pilgrimes. vol. III, p. 95.

${ }^{57}$ Purchas, Samuel, (1905). Purchas His Pilgrimes. vol. III, : p. 95.

${ }^{58}$ Purchas, Samuel, (1905). Purchas His Pilgrimes. vol. III, p. 95.

${ }^{59}$ Sainsbury, W. Noel, (1870). Calendar of State Papers, 1617-1621, p. 102.

${ }^{60}$ Sainsbury, W. Noel, (1870). Calendar of State Papers, 1617-1621, p. 273.
} 
English Company was to receive one-third of the Moluccan spices and half the Javanese pepper. Both the companies had to contribute for the defence of their common interest for which a Council of Defence (constituted of four principal officers of each company) set up. Forts were to remain in the hands of the party who had already held them; each party was to furnish ten large ships, and the council was to decide the numbers of smaller vessels to be contribute. ${ }^{61}$

The Treaty of Defence in 1619 had freed the English in the Far East from active hostilities, on the parts of the Dutch, and give right to the shelter of the Dutch fortresses and a share in the trade. However, these benefits accompanied by financial obligations, which in the weak state of the English proved far too heavy to bear. They were to pay one-third of the garrison charges in the Moluccas, Bandas and Amboyna, and one-half of those at Pulicat. ${ }^{62}$ To meet these burdens it was necessary that they should drive a larger trade than before; but, a far being able to do this, the President and Council at Batavia found themselves almost at their wits end of money.

The Dutch Governor Jan Pieterszoon was not happy with the treaty. He had a vision based on reality in Asia trade in the Spice Archipelago. By the Treaty of Council, which both side agree for joint venture, Coen asked the English to send an army to the Banda Islands to finally bring the terms of trade at the end of 1620 . Coen intention was mention to the English, and in the new Council of Defence, they were ask if they, under the terms of agreement, would participate. The English reply that they would gladly joined the expedition, but $\mathrm{t}$ they lacked the ships and troops to do so. ${ }^{63}$ Coen arrived in February 1622, saw English had opened a factory at Lonthor, and annoy of this new arrangement. These native prefer English and had treaty in 1619, the document says: 'this islands the country people desired to surrender on the same terms as the others, not to trade with any other nation but the English. ${ }^{64}$ Thus, English consider as heir possession. The English captain Robert Randall of Pooloroon took possession of Lonthor and continued the English factory there. Soon after the arrival of the Dutch in Neira, fearing an attack of the island, Randall wrote to the Coen that the island belonged to the King of England, and that as an accord had been made in England between the English and Dutch Companies, he should forbear to use any violence against said island. ${ }^{65}$

However, the Dutch never acknowledge the English possession of Lonthor. The Dutch attacked and subdued the island, and during the conflict, Randell along with his two English's and eight Chinese kept prisoners. The Dutch have taken the factory violently in spite of the English, which made no resistance, later they cut off three Chinese's heads, and dragged before the Captains and General. On the way through the castle, they were ordered to go over a wall 12 feet high, and when Randell refused they threw him over, where he was much bruised, and broke his neck. They beat him grievously and put them all in irons for 18 days until the coming of the ship Royal Exchange. ${ }^{66}$

Nahaniel Courthoppe, chief of the English at Pooloroon having been at Lonthor to receive its surrender intercepted on his return on November 1620, and killed by the Dutch. ${ }^{67}$ Actually, the Dutch had intelligence of the publication of the accord at Bantam, in March 1619, and they sent secretly to the islands in those parts where they had trade, to prevent the English to take spices. ${ }^{68}$ In November 1620, a Dutch ship was taken by the Bandanese off the coast at Pooloroon, a letters from the Dutch General to the Dutch in Pooloway and Neira, came to the hands of Robert Hayes, captain of the English at Pooloroon. When he open the letter, the effect being that, there was a peace

\footnotetext{
${ }^{61}$ Foster, William, (ed.), (1906). The English Factories in India, 1618-1621, pp. xlii-xliii.

${ }^{62}$ Sainsbury, W. Noel, (1870). Calendar of State Papers, 1622-1624: pp. 98-100.

${ }^{63}$ Purchas, Samuel, (1905). Purchas His Pilgrimes, vol. V: p. 137.

${ }^{64}$ Sainsbury, W. Noel, (1870). Calendar of State Papers, 1617-1621: p. 257.

${ }^{65}$ Sainsbury, W. Noel, (1870). Calendar of State Papers, 1622-1724, p. 53.

${ }^{66}$ Sainsbury, W. Noel, (1870). Calendar of State Papers, 1622-1624: p. 53. And see also, Purchas, Samuel, (1905).

Purchas His Pilgrimes, vol. V: p. 138.

${ }^{67}$ Purchas, Samuel, (1905). Purchas His Pilgrimes, vol. V: pp. 129, 140. And see also, Sainsbury, W. Noel, (1870). Calendar of State Papers, 1622-1624: p. 53.

${ }^{68}$ Purchas, Samuel, (1905). Purchas His Pilgrimes, vol. V: p. 140.
} 
concluded in England they should use all means to engross all the spice they could before the arrival of the English fleet. ${ }^{69}$

In the aftermath, it is one of the darkest in the history of Dutch colonial expansion and its policy towards the native people. It was a bloody campaign under Coen, which associated with terror and devastation to establish their authority, and secure the price of commercial monopoly. When the Dutch finally captured Lonthor, about 13,000 Bandanese were decimated in a couple of weeks. The population of the whole small island nation was exterminated. The English could do nothing: 'when the inhabitants asked us if we could and would defend them, but perceiving we were not able to defend ourselves much less to secure them: they were forced to yield themselves and the islands into his hands. ${ }^{70}$ Only few managed to escape to the neighbouring islands Kai, Cerram and the small islands of Goram Archipelago. ${ }^{71}$ The remaining small-terrified population of the outer islands Rosingain was deported: "they forced the islanders to deliver up the principal of their children prisoners slew many of the Bandanese, and carried of all the ships and boats and 1200 prisioners (mostly women and children), to Jacatra. ${ }^{, 72}$ The Dutch also seized all the English goods at Lonthor, valued at 7,651rials of eight. ${ }^{73}$ After this incident, the English remained only at Nailaka in the Banda islands.

The Treaty of 1619 brought several unresolved issue, particularly that of the exact status of the English in Dutch settlements, which brought acrimonious controversy. The English complained that they were made amenable to the Dutch tribunals, and forced to pay excise and other duties. In complaint letters to the East India Company of the Netherlands; it writes:

'The Treaty of July 1619, had been broken by the Dutch; by not restoring the pepper, silk and other goods they had taken and brought into the Netherlands; by imprisoning, imposing fines inflicting corporal punishment in the market places, and keeping in irons the English; by not suffering the English to buy merchandise and victuals of the Indians at Jacatra, before the Dutch were first served; by denying the English to finish their house at Jacatra; by denying to load pepper they had brought from the king of Sangora; by imposing at Jacatra new and great taxes and tolls upon the English goods, and levying great fines for non-payment; by deny the English importation and sales of victuals and clothing in the Moluccas, Banda, and Amboyna the most profitable merchandise for those place. ${ }^{74}$

The gravest question was on the Bandas and Moluccas, the Dutch claimed to exclude the English from the Moluccas and the Bandas, on the ground that the trade in these islands, the sole sources of the more valuable spices, and claim by the Dutch in consequence of concessions procure from the native chiefs. However, after the Treaty of 1619, the English were allowed to benefit one third of the product in the spice trade in the Bandas and Moluccas. But the Dutch: 'prevent the English from enjoying a third part of the fruits of the Moluccas, which is contrary to the treaty and deny the English liberty of paying their men as the Dutch do with cloths and victuals, ${ }^{75}$ and the English protest: "we do more than pay the whole charge in Banda, and there is little hope that Amboyna and the Moluccas will prove better. ${ }^{76}$ Moreover, the Dutch forts were increasing without the knowledge of the English and the English paid this new fort maintenance: 'their new buildings in Banda amount an excessive sum. Excessive gifts and extraordinariness was given without our knowledge. ${ }^{, 77}$

The Treaty of 1619 , turned out as was expected practically ineffective. After 20 months of existence, the English were very much in serious trouble and both the English and Dutch were compelled to reopen fresh negotiations. The dispute continued to arise between the two companies and as frequently as before, and the English Company made the same complaints louder and bitterer. After many fruitless efforts to settle the difference, a fresh

${ }^{69}$ Sainsbury, W. Noel, (1870). Calendar of State Papers, 1622-1624: p. 53.

${ }^{70}$ Samuel Purchas 1905. Vol. V: p. 140.

${ }^{71}$ Sainsbury, W. Noel, (1870). Calendar of State Papers, 1622-1624: p. 202.

${ }^{72}$ Sainsbury, W. Noel, (1870). Calendar of State Papers, 1622-1624: p. 54. And Purchas, Samuel, (1905). Purchas His Pilgrimes, vol. V: pp. 140-141.

${ }^{73}$ Sainsbury, W. Noel, (1870). Calendar of State Papers, 1622-1624: p. 53.

${ }^{74}$ Sainsbury, W. Noel, (1870). Calendar of State Papers, 1622-1624: p. 11.

${ }^{75}$ Sainsbury, W. Noel, (1870). Calendar of State Papers, 1622-1624: p. 95.

${ }^{76}$ Sainsbury, W. Noel, (1870). Calendar of State Papers, 1622-1624: p. 59.

${ }^{77}$ Sainsbury, W. Noel, (1870). Calendar of State Papers, 1622-1624: p. 234. 
treaty was recommend by the commission on 28 November 1621 . There were several points of difference in both. The question of restitution involved the English ships that had been taken by the Dutch; the value of goods seized from the English at Lonthor and elsewhere, and charges the seized of Bantam. The talks come to the main points of difference mainly on four points; 1 . Lessening the number of the ships of defence; 2 . Jurisdiction in the East Indies; 3 . The choice of an indifferent place of residence for the Council of defence there; and 4. The building of forts. Before this decision was actually carried out there occur the famous 'Massacre of Amboyna,' ten English men being tortured and put to death, after an irregular trial, on the charge of conspiring to capture the Dutch fortress on February $271623 .^{78}$ With this outrage the relation between these two nations evaporate, all hopes of future cooperation in the Far East was not possible anymore.

No evidence ever discovered on the charge; no criminatory papers only from a confession extorted by agony from two soldiers in the Dutch soldiers were found. Not more than twenty Englishmen were on the island, while the Dutch had 300 in the fort, and several garrisons in the neighbourhood islands. The English had no arms ammunition, and not a single ship; while the Dutch had eight vessels nearby. An inquiry opened and the reports inflamed the public mind of England. Reprisals were demanded; but the Dutch humbled except the misconduct. The reply came:

'their trade they may boldly proceed without hazard, for the states and the Prince of Orange have written to their General, both for sending hither the Amboyna Governor and Judges, and to hold good friendship with the English in general, and in particular to accomplish their desire in the three points. According to the states' answer: the first of which is ample and satisfactory; the second saves their sovereignty in causes not belong to the general of the two companies; the third has two main restriction - as to not building forts within 30 miles of the Dutch forts and forbearing the Moluccas, Banda, and Amboyna. ${ }^{, 79}$

In spite of goodwill gesture by the Dutch, the English decided to dissolve the factories at Amboyna, Banda and Moluccas. ${ }^{80}$ The English cannot afford ten ships to station at Moluccas as by the agreement of $1619 .{ }^{81}$ The charges to maintain fort also put to a heavy toll for the English. It was also a plan for the Dutch to make themselves absolute master of the trade in the East Indies. Since joining with the Dutch, the English dissolved four factories at Patani, Pulicat, Siam and Hirado. Since they close their factory at Moluccas and Banda, the only ones left were those at Masulipatnam, Acheen, Jambi, Japara, and Macassar. Officially, the English left from the Treaty of 1619, after the Amboyna Massacre in February 1623.

Nevertheless, the Dutch offered to settle again in Moluccas and Banda and: 'enjoy those privileges granted by the contract and have declared our readiness to join in the common defence. ${ }^{82}$ Nevertheless, the English were not ready to comply given the charges that were unable to maintain. The English share of the fort charges came to 549 rails of eight per month, in addition to their own expenses, while the whole sum received from Batavia during the year was only 20,000 rials. Such being the state of affairs, the Pulicat factors come the conclusion that they could do better elsewhere. There were many other places on the coast where cotton goods could be obtain without paying costly garrison charges. On February 8, 1623, they wrote to Masulipanam that they had received overtures: 'from the greatest man in the quarter, who so kindle invites us to seat ourselves within his authortiy, wih his firman that wee shal live upon what conditions wee shall desire and to our harts contente; and wee well knowe the place will afford all manner of our desired investment and divers othere sotrs which wee ar hers furnished. ${ }^{83}$ However, the President at Batavia had already decided that it was not worthwhile to maintain a factory at Pulicat, and on April 11 1623 , they formerly determined to withdraw the establishment. ${ }^{84}$ The reason given were the need of reducing expenses and the fact that Coromandel cloths would not now be require, when the English factories in the Moluccas and Banda close.

The Dutch at Batavia offered no objection to the proposal, though they intimated that, should the English desire at any time to return to Pulicat, the question would arise as to their paying part of the cost of the garrison

${ }^{78}$ Foster, William, (ed.), (1908). The English Factories in India, 1622-1623, p. 206.

${ }^{79}$ Sainsbury, W. Noel, (1870). Calendar of State Papers, 1622-1624: pp. 425-426.

${ }^{80}$ Foster, William, (ed.), (1908). The English Factories in India,1622-1623: pp. 194, 224, 246.

${ }^{81}$ Sainsbury, W. Noel, (1870). Calendar of State Papers, 1622-1624: pp. 96. 111. 210.

${ }^{82}$ Sainsbury, W. Noel, (1870). Calendar of State Papers, 1622-1624: p. 147.

${ }^{83}$ Foster, William, (ed.), (1908). The English Factories in India, 1622-1623: p. 193.

${ }^{84}$ Foster, William, (ed.), (1908). The English Factories in India, 1622-1623: p. 194. 
during their absence. The ship Ruby was accordingly dispatched at once to Pulicat with orders for the dissolution of the factory. She reached her destination on June 18; the merchants embarked their goods, and on 1 July 1623, sailed away from Masulipatnam. Thus, ended the English-Dutch partnership on the Coromandel Coast. ${ }^{85}$

After the English withdrew in the Spice Islands, there left with only two major powers the Dutch and Spanish. The king of Ternate is ally with the Dutch, and the king of Tidore with the Spaniards. The Dutch, finding themselves in quite possession of Amboyna and Banda have resolved only to hold defensive war with the Spaniards. The Ternateans holding it no reason that they should war with their neighbours, the Tidoresse, to their own concern and hindrance of commerce for content of the Dutch, made a truce with them in 1621, who now sell spices to the Spaniards at a dearer rate that they can to the Dutch. The native islanders receiving many discontents from the Dutch and not cared to pluck their cloves as in foretimes, having made peace found other means to maintain themselves. Since the truce, the inhabitants of Ternate were consider a friend to the Dutch, but there were unresponsive because of the cruelty to their allies in Banda, and encroaching upon the king of Ternate's possessions, and desire to hold the Spaniards and Dutch in equal balance. ${ }^{86}$

The Dutch ambition changed in the later year as they pursue their career, carrying war against the Spaniards by attacking in their own settlements among the Philippines.' In 1627, Coen was again, installed Governor-General, and his vigour at once gave an impulse to the Company's policy. The Spaniards had not the power; the Dutch had not always the inclination to become the destroyers of this system. The Council of Batavia, occupied with other schemes, directed little notice to the transaction on the northern borders of the Archipelago. Troubles in the Moluccas continued to render their possession of the group uneasy and dangerous. To secure it by fixing their influence on one of the most important islands they dispatched an envoy to Macassar in Celebs, where their first treaty with the king was concluded in $1639 .{ }^{87}$ The revolt of 1652 by the Moluccans was contained by very rude measures and cruelty. Ternate was occupied, and the king was exiled at Batavia under a harsh term. He continued to encourage the resistance of his chiefs, and their struggle was courageous and protracted. One of a chief patriarch, who had long been defended an interior region, saw it would be fruitless to continue, made terms with the Dutch, engaged to negotiate his religion for his life, and surrendered his family. But the Dutch keep promise only on paper, when the ink was dried he was considered unworthy of honour and promise, the Dutch dragged him, with his mother, sister, and brother to prison, and this unfortunate chief was sent to gallows. ${ }^{88}$

The king of Ternate held in durance at Batavia, forced to agree, by a written treaty, to destroy all the cloves trees in his dominions. This was the original ground of conflict, and the means of settling it were equally characteristic of the spirit, which then animated the merchants-governor of the east. It was the unhappy passion of monopoly, which betrayed them into their greatest follies and their greatest crimes. The situation was worse at Amboyna when the governor of Dutch Vlaming, when exercised his will of power, sentenced twenty Moluccan chiefs to death. ${ }^{89}$ In February the next year, another execution of the captive prince of the Moluccas took place. Prince Tertillo, a distinguished warrior, walked to gallows with a face rendered magnificent by the undaunted, and offered his neck, heroic for the love of his country. Saydy, another great chief was also mutilated in front of Vlaming, the dying chief turned aside his head, to avoid looking and the barbarian hacked him to pieces, and while his limbs yet quivered with warmth of life, scattered them among the rocks. ${ }^{90}$

Even the natives converted to Christianity rose against their oppressors. The most remarkable of these insurrections was John Pays, a native of Amboyna distinguished for his sacrifices to the alien religion. He was put to death along with many noblemen for the fear the spectacle might occasion a commotion among the inhabitants. The inhabitants of the Moluccas continued to revolt, though with less vigour, down to the year 1671. The last insurrection of the Moluccas broke out in 1680, and continued during the whole of that and the following year. These were the last efforts of those islanders to maintain their independence. Enfeebled and broken-spirited by their ineffectual efforts, they surrendered with the illusion of freedom and their livelihood will be restore by the foreign conquerors. The Dutch now enabled to carry their principal of commercial policy into the most rigid practice. The

\footnotetext{
${ }^{85}$ Foster, William, (ed.), (1908). The English Factories in India, 1622-1623: p. 246.

${ }^{86}$ Sainsbury, W. Noel, (1870). Calendar of State Papers, 1622-1624, p. 210

${ }^{87}$ Crawford, John, (1820). History of the Indian Archipelago, Vol. II, p. 439.

${ }^{88}$ Crawford, John, (1820). History of the Indian Archipelago, vol. II, p. 440.

${ }^{89}$ Hoarse, St. John, (1853). The Indian Archipelago. vol. I, p. 335.

${ }^{90}$ Crawford, John, (1820). History of the Indian Archipelago, vol. II, p. 442.
} 
consumption of spices decreased as their prices rose, and the Spice Islands henceforth ceased to be of value and importance.

The monopoly of the spices was secured by the conquest of Macassar in the year 1669. It was the avidity of the Dutch to secure the monopoly of the spices, and the natural hostility of the people of Celebes, towards those who unjustly and violently excluded them from a traffic in which they had so long and so extensively engaged, one which was so beneficial to them, and so natural to their geographical and moral situation, which produced the long war between them.

\section{References}

[1] Burney, James, (1803). A Chronological History of the Discoveries in the South Sea. Part. I, London: Luke Hansard.

[2] Cortsao, Armando, (ed.), (2005). The Sumo Oriental of Tomes Pires. 2vols. New Delhi: Asian Educational Services.

[3] Crawford, John, (1820). History of the Indian Archipelago. vol. III, Edinburgh: Archibald Constable and Co.

[4] Crooke, William. (ed.), (2007). Tavernier. Travels in India. Between 1640-1676, vol. I, New Delhi: Asian Educational Services. 2nd edition.

[5] Dames, L.M. (ed.), (1989). The Book of Duarte Barbosa. vol. II, New Delhi: Asian Educational Services.

[6] Fayle, C. Earnest, (ed.), (1997). Voyages to the East Indies. New Delhi: Asian Education Services.

[7] Foster, William, (ed.), (1905). John Jourdian, The Journal of a Voyage to the East Indies, London: Hakluyt Society

[8] Foster, William, (ed.), (1906-1908). The English Factories in India, 1618-1621 and 1622-1623, Oxford: Clarendon.

[9] Gray, Albert, (ed.), (2000). The Voyage of Francois Pyrard. 2vols. New Delhi: Asian Educational Services Reprint.

[10] Hamilton, Alexander, (1995). A New Account of the East-Indies, vol. I, New Delhi: Asian Educational Services.

[11] Hoarse, St. John, (1853). The Indian Archipelago. vol. I, London: Longman, Brown, Green, and Longmans.

[12] Markham, Clements, (ed.), (1911). Andres de Urdaneta, Narrative of the Voyage to Malucos or Spice Islands by the Fleet under the Orders of the Commendador Garcia Jofree de Loaysa, in Early Spanish Voyages to the Straits of Magellan, London: Hakluyt Society

[13] Purchas, Samuel, (1905). Purchas His Pilgrimes, vol. II, vol. III and vol. V, Glasgow: James MacLehose and Sons.

[14] Satow. M. Ernest, (ed.), (1900). The Voyage of Captain John Saris to Japan. 1613, London: Hakluyt Society.

[15] Sainsbury, W. Noel, (1870). Calendar of State Papers, 1617-1621 and 1622-1624, London: Longman \& Co. and Trubner \& Co.Paternoster Row.

[16] Tuckey, James Hingston, (1815). Maritime Geography and Statistics. vol. II, London: Black Parry and Co. 